\title{
PENAMPILAN PRODUKSI AYAM KAMPUNG YANG DI BERI JAMU TERNAK MELALUI AIR MINUM
}

\author{
Yuliana $^{1}$, Nuraini ${ }^{2,}$ dan Amiluddin Indi ${ }^{2}$ \\ ${ }^{1}$ Alumnus Fakultas Peternakan Universitas Halu Oleo \\ ${ }^{2}$ Jurusan Peternakan Fakultas Peternakan Universitas Halu Oleo \\ Email: yuliana.fapet@yahoo.com
}

\begin{abstract}
ABSTRAK
Penelitian ini dilaksanakan dengan tujuan untuk mengetahui pengaruh pemberian jamu ternakterhadap penampilan produksi ayam kampung.Bahan yang digunakan adalah ayam kampung sebanyak 48 ekor yang dibagi ke dalam 12 petak kandang,terdiri atas 4 perlakuan A0 yaitu Air minum tanpa jamu ternak,A1 yaitu air minum dengan jamu ternak1\% perliter air ,A2 yaitu air minum dengan jamu ternak 2\% perliter air dan A3 yaitu air minum dengan jamu ternak 3\% perliter air dengan 3 ulangan. Data yang diperoleh dianalisis menggunakan analisis ragam Rancangan Acak Lengkap (RAL). Hasil penelitian menunjukkan bahwa pemberian jamu ternak melalui air minum berpengaruh tidak nyata $(\mathrm{P}>0,05)$ terhadap konsumsi air minum, konsumsi pakan, pertambahan bobot badan dan konversi pakan.
\end{abstract}

Kata kunci : Jamu ternak, Penampilan produksi, Ayam kampung.

\begin{abstract}
This study was conducted to understand the effect of poultry herbs on native chicken performance. Materials used were chicken as many as 48 birds which were divided into 12 plot cages, consist of 4 treatment as follow: A0 (drinking water without poultry herbs), A1 (drinking water with poultry herbs as much as $1 \%$ / liters of water), A2 (drinking water with poultry herbs as much as $2 \%$ / liters of water), A3 (drinking water with poultry herbs as much as 3\%/liters of water), and 3 times replication. Data obtained was analyzed by using completely randomized design (CRD). Result of this research showed that application of poultry herbs through drinking water has no real effect $(P>0.05)$ on drinking water intake, feed intake, weight gain, and feed conversion.
\end{abstract}

Keywords: Poultry herbs, Performance, Native chicken.

\section{PENDAHULUAN}

Ayam kampung merupakan ayam lokal di Indonesia yang kehidupannya sudah lekat dengan masyarakat. Ayam kampung mempunyai kelebihan pada daya adaptasi tinggi karena mampu menyesuaikan diri dengan berbagai situasi, kondisi lingkungan dan perubahan iklim serta cuaca setempat. Ayam kampung memiliki bentuk badan yang kompak dan susunan otot yang baik. Kondisi yang ada terkait dengan masalah utama dalam pengembangan ayam kampung adalah rendahnya produktivitas. Peranan ayam kampung dalam kehidupan masyarakat terutama para petani di pedesaan cukup menonjol dalam rangka meningkatkan taraf hidup pada umumnya. Namun demikian, peranan yang cukup besar ini kurang ditunjang dengan kecepatan pertumbuhan ukuran tubuhnya.

$$
\text { Ayam kampung di Sulawesi }
$$

Tenggara umumnya, dipelihara secara tradisional atau umbaran dan tanpa pengontrolan perkawinan. Dengan kondisi pemeliharaan tersebut, ternak ini hanya dijadikan sebagai ternak konsumsi keluarga ataupun dijual. Bila ditinjau 
lebih jauh, ayam kampung belum menunjukkan produktivitas yang optimum karena beberapa faktor. Upaya yang dapat dilakukan untuk meningkatkan produktivitas ayam kampung adalah dengan perbaikan manajemen, pakan, breeding dan lingkungan.

Indonesia sebagai negara tropis memiliki aneka tanaman yang memiliki khasiat yang bermanfaat bagi berbagai kebutuhan manusia. Aneka produk jamu yang dikonsumsi oleh masyarakat luas merupakan produk olahan yang berasal dari berbagai jenis tanaman yang tumbuh dan berkembang di negeri ini. Penggunaan jamu tradisonal yang berasal dari aneka tanaman lokal selain untuk pengobatan berbagai jenis penyakit, juga untuk kebugaran tubuh dan memperbaiki kesehatan reproduksi.

Rangkaian penelitian Agustina (2006) dan Agustina et al (2009) serta Agustina (2010), pada tahun 2006 menunjukkan Rangkaian penelitian Agustina (2006) dan Agustina et al (2009) serta Agustina (2010), pada tahun 2006 menunjukkan penggunaan ramuan herbal dalam bentuk cair maupun serbuk mampu menghambat bakteri Gram positif dan Gram negatif, karena bahan ramuan mengandung zat bioaktif. Penelitian 2009 menunjukkan perlu pengurangan jenis bahan yang diduga memiliki zat bioaktif yang sama. Pada tahun 2010, penggunaan ramuan herbal cair sebanyak $2,5 \mathrm{ml} / \mathrm{l}$ air minum, merupakan hasil terbaik ditinjau dari performa dan kelainan histopatologi organ dalam.

Jamu ternak merupakan bahan suplemen yang dapat meningkatkan pertambahan bobot badan dan menurunkan tingkat konversi pakan (FCR) serta meningkatkan kekebalan tubuh. Inilah salah satu trikmen untuk menyelesaikan rumusan masalah di atas dalam penelitian ini, sehingga peneliti ingin mengangkat judul "Penampilan Produksi Ayam Kampung yang Diberi Jamu Ternak Melalui Air Minum".

\section{METODOLOGI PENELITIAN}

\section{Lokasi dan Waktu Penelitian}

Penelitian ini dilaksanankan pada Bulan Desember sampai dengan Februari 2016, yang berlokasi di unit kandang Pembibitan Unggas Fakultas Peternakan Universitas Halu Oleo Kendari.

\section{Prosedur Penelitian}

\section{Bahan}

Bahan yang digunakan untuk penelitian terdiri atas ayam kampung 48 ekor, pakan yang diformulasi sendiri dengan menggunakan bahan pakan konsentrat, jagung kuning, dan dedak halus, serta jamu ternak yang terdiri dari lengkuas 250 gr, jahe 250 gr, gula merah 250 gr, kencur 250 gr, bawang putih 250 gr, daun sirih 50 gr, EM4 500 ml, kunyit 250 gr, air 10 liter.

Peralatan yang digunakan dalam penelitian ini terdiri atas kandang ayam 12 unit, kandang litter yang berukuran $0,6 \mathrm{~m} \mathrm{x}$ $0,7 \mathrm{~m} \times 0,6$. Kandang masing-masing dilengkapi dengan tempat pakan dan tempat minum, serta lampu pijar 15 watt sebagai penghangat dan penerang.

Alat lain yang digunakan yaitu timbangan ditigal (untuk menimbang bobot badan ayam,dan bahan pakan), gelas ukur untuk mengukur sisa air minum, blender untuk menghaluskan bahan-bahan jamu ternak, pisau untuk memotong bahan jamu ternak, dan alat tulis untuk mencatat serta kamera untuk dokumentasi selama penelitian. 


\section{Prosedur Penelitian}

\section{a. Pembuatan Jamu Ternak}

Proses pembuatan jamu ternak adalah:

\begin{tabular}{l} 
Tiap bahan ditimbang dengan jumlah \\
takaran $(\mathrm{g})$ \\
1. Lengkuas $250 \mathrm{gr}$ \\
2. Jahe $250 \mathrm{gr}$ \\
3. Kencur $250 \mathrm{gr}$ \\
4. Bawang putih $250 \mathrm{gr}$ \\
5. Daun sirih $50 \mathrm{gr}$ \\
\hline
\end{tabular}

Seluruh bahan dicuci sampai bersih dan diiris tipis

\section{Masing-masing bahan diblender,} disaring, dan diambil ekstraknya

Ekstrak jamu ternak dicampur dan ditambahkan dengan 250 g gula merah dan $500 \mathrm{ml}$ laruran EM4

Campuran ekstrak jamu ternak, gula merah, dan laruran EM4 ditambah dengan 10 liter air, diaduk merata dan ditempatkan dalam jergen yang tertutup rapat selanjutnya difermentasi selama 5hari sampai tidak terbentuk gas

\section{Gas yang terbentuk selama proses fermentasi dikeluarkan dengan membuka tutup wadah lalu diaduk selama 5 menit kemuadian ditutup kembali.}

\section{b. Persiapan Kandang}

Kandang dan peralatannya disucihamakan terlebih dahulu, untuk mencegah kontaminasi mikroorganisme yang merugikan. Selanjutnya lantai kandang diisi serbuk gergaji sebagai lantai kandang.

\section{Pelaksanaan Penelitian}

\section{a. Pengacakan Perlakuan terhadap petak kandang}

Ayam kampung yang digunakan sebanyak 48 ekor. dibagi menjadi 12 petak kandang. Tiap petak diisi dengan 4 ekor ayam kampung yang ditempatkan secara acak

\section{b. Pemeliharaan Ayam Kampung}

Ayam kampung dipelihara dari umur DOC sampai umur 2 bulan.Pemberian ransum diberikan $2 \mathrm{kali}$ sehari pada pukul 07.15 dan 17.00, kemudian sisa ransumnya ditimbang.Air minum yang mengandung jamu ternak diberikan setiap hari yaitu pada pagi hari secara adlibitum.Vaksinasi dilakukan pada umur 4 hari yaitu vaksinasi ND/tetelo dengan metode tetes mata.

\section{Rancangan Penelitian}

Rancangan penelitian yang digunakan adalah Rancangan Acak Lengkap dengan 4 perlakuan dan 3 ulangan, masing-masing ulangan terdiri atas 4 ekor ayam. Model matematika yang digunakan yaitu :

$Y \mathrm{ij}=+\alpha \mathrm{i}+\varepsilon \mathrm{ij}$

Yij = Nilai pengamatan pada ulangan ke-i dan ulangan ke-j

$$
\begin{aligned}
& \mu \quad=\text { Nilai rata-rata umum } \\
& \alpha \mathrm{i}=\text { Pengaruh perlakuan ke-i } \\
& \varepsilon \mathrm{ij}=\text { Pengaruh galat dan perlakuan }
\end{aligned}
$$

\section{Variabel Penelitian}

Variabel yang diamati dalam penelitian ini adalah:

a. Konsumsi air Minum

Konsumsi air minum dilihat dengan selisih antara air minum yang diberikan dengan sisa air minum dan diukur dengan menggunakan gelas ukur 
pada setiap pagi hari. Rumus Konsumsi air minum $(\mathrm{ml} /$ ekor/hari $)=$ Jumlah air minum yang diberikan - sisa air minum.

b. Konsumsi Pakan

Konsumsi pakan dilihat dengan selisih antara pakan yang diberikan dengan sisa pakan yang ada dengan menimbang pakan tersebut. Rumus Konsumsi pakan (g/ekor/hari) = Jumlah pakan diberi(pagi) - sisa pakan yang ada dibagi dengan (jumlah ayam $\mathrm{x}$ lama penelitian).

a. Pertambahan Bobot Badan

Pertambahan berat badan dapat dihitung dengan mengurangi berat badan akhir dengan berat badan awal kemudian dibagi dengan (jumlah ayam $\mathrm{x}$ lama pemeliharaan).

Rumus pertambahan bobot badan adalah :

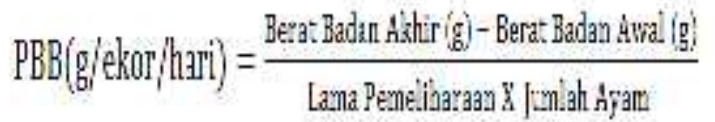

\section{b. Konversi Pakan}

Konversi pakan dapat dihitung berdasarkan perbandingan antara total pakan yang dikonsumsi dengan pertambahan bobot badan.
Rumus Konversi Pakan adalah :

Konversi Pakan $=\frac{\text { Konsumsi pakan (g/ekor/hari) }}{\text { Pertambahan bobot badan (g/ekor/hari) }}$

\section{Analisis Data}

Sidik ragam digunakan untuk mengetahui pengaruh perlakuan terhadap variabel penelitian. Selanjutnya uji beda nyata digunakan untuk melihat pengaruh antar perlakuan terhadap variabel penelitian.

\section{HASIL DAN PEMBAHASAN}

\section{Konsumsi Air Minum}

Konsumsi air minum dapat diukur dengan selisih antara air minum yang diberikan dengan sisa air minum dengan menggunakan gelas ukur. Air minum merupakan unsur yang paling dibutuhkan oleh makhluk hidup, tidak terkecuali pada ayam kampung. Rataan konsumsi air minum ayam kampung selama penelitian dengan pemberian jamu ternak dapat dilihat pada Tabel 4.

Tabel 4. Rataan Konsumsi Air Minum Ayam Kampung yang Diberi Jamu Ternak Melalui Air Minum (ml/ekor/hari)

\begin{tabular}{|c|c|c|c|c|}
\hline \multirow[t]{2}{*}{ Ulangan } & \multicolumn{4}{|c|}{ Perlakuan } \\
\hline & A0 & A1 & A2 & A3 \\
\hline 1 & 102.129 & 106.571 & 114.428 & 110.157 \\
\hline 2 & 120.149 & 117.785 & 106.214 & 80.2142 \\
\hline 3 & 105.571 & 111.857 & 104.142 & 130.357 \\
\hline Jumlah & 327.849 & 336.213 & 324.784 & 320.7282 \\
\hline Rata-rata & 109.283 & 112.071 & 108.2613 & 106.9094 \\
\hline
\end{tabular}

Berdasarkan Tabel 4, rataan konsumsi air minum ayam kampung yang diberi jamu ternak secara berturut-turut adalah $\mathrm{A} 0=$ $109,28 \mathrm{ml}, \mathrm{A} 1=112,07 \mathrm{ml}, \mathrm{A} 2=108,26$ $\mathrm{ml}$ dan $\mathrm{A} 3=106,90 \mathrm{ml}$. Hasil analisis ragam menunjukan bahwa penggunaan jamu ternak sampai 3\% dalam air minum tidak berpengaruh nyata $\quad(\mathrm{P}>0,05)$ terhadap konsumsi air minum ayam kampung. Hal ini menujukkan bahwa penggunaan jamu ternak dalam air minum sampai 3\% tidak menganggu indra penciuman maupun indra perasa ayam kampung. Sebagaimana dikemukakan oleh 
Wahyu (2004) bahwa rasa (taste) pada ayam memegang peranan yang relatif kecil untuk menentukan banyaknya pakan dan air minum yang dikonsumsi.

Banyaknnya pakan dan air minum yang dikonsumsi tergantung pada tingkat keaktifan ternak terhadap lingkungan serta fase pertumbuhan menurut Arifin (2002) bahwa jumlah konsumsi air minum lebih nyata dipengaruhi oleh suhu lingkungan, jumlah dan keadaan pakan yang diberikan. Perbedaan konsumsi air minum yang tidak nyata disebabkan ayam berada pada umur dan fase pertumbuhan yang sama.

\section{Konsumsi Pakan}

Konsumsi pakan merupakan kegiatan memasukkan ransum kedalam saluran pencernaan untuk memenuhi kebutuhan nutrisi ayam kampung sehingga mampu memenuhi kebutuhan produksinya. Konsumsi pakan adalah jumlah pakan yang dikonsumsi setiap ekor selama penelitian. Rataan konsumsi pakan ayam kampung selama penelitian dengan pemberian jamu ternak dapat dilihat pada Tabel 5.

Tabel 5. Rataan Konsumsi Pakan (gram/ekor/hari ) Ayam Kampung yang Diberi Jamu Ternak Melalui Air Minum.

\begin{tabular}{lllll}
\hline Ulangan & Perlakuan & & & \\
\cline { 2 - 5 } & A0 & A1 & A2 & A3 \\
\hline 1 & 47.48 & 51.85 & 49.69 & 53.54 \\
2 & 47.98 & 52.92 & 52.51 & 47.48 \\
3 & 51.05 & 55.07 & 59.58 & 53.58 \\
\hline Jumlah & 146.51 & 159.84 & 161.78 & 154.6 \\
\hline Rata-rata & 48.83 & 53.28 & 53.92 & 51.53 \\
\hline
\end{tabular}

Berdasarkan Tabel 5, rataan konsumsi ayam kampung yang diberi jamu ternak secara berturut-turut adalah $\mathrm{A} 0=48,83 \mathrm{~g}$, $\mathrm{A} 1=53,28 \mathrm{~g}, \mathrm{~A} 2=53,92 \mathrm{~g}$, dan $\mathrm{A} 3=$ 51,53g. Disini terlihat bahwa ayam kampung yang mendapat perlakuan jamu ternak konsumsi ransumnya lebih tinggi jika dibandingkan dengan ayam kampung yang mendapat perlakuan kontrol. Hal ini kemungkinan disebabkan oleh beberapa kandungan bahan jamu seperti minyak atsiri yang dikandungnya antara lain galangol, galangin, alpinen, kamfer, dan methylcinnamate yang dapat meningkatkan nafsu makan pada ayam kampung menurut Anonim (2011). Hasil sidik ragam menunjukkan bahwa pada masing-masing perlakuan berpengaruh tidak nyata $(\mathrm{P}>0,05)$.

Hasil ini menunjukkan bahwa penggunaan jamu ternak pada ayam kampung hingga 3\% melalui air minum tidak menyebabkan perbedaan konsumsi ransum yang nyata antar perlakuan. Tillman et al. (1989) menyatakan jantung, otak dan semua jaringan tubuh lainnya dalam hal ini tidak termasuk penggemukan karena penggemukan merupakan pertambahan dalam bentuk lemak (Anggorodi, 1994).

Rataan pertambahan bobot badan ayam kampung selama penelitian dengan pemberian jamu ternak dapat dilihat pada Tabel 6. 
Tabel 6. Rataan Pertambahan Bobot Badan Ayam Kampung yang Diberi Jamu Melalui Air Minum (g/ekor/hari).

\begin{tabular}{lllll}
\hline Ulangan & \multicolumn{2}{l}{ Perlakuan } & & \\
\cline { 2 - 5 } & $\mathrm{A} 0$ & $\mathrm{~A} 1$ & $\mathrm{~A} 2$ & $\mathrm{~A} 3$ \\
\hline 1 & 8.54 & 10.14 & 12.25 & 14.14 \\
2 & 10.03 & 13.17 & 9.71 & 10.85 \\
3 & 11.21 & 13.1 & 13.96 & 12.17 \\
\hline Jumlah & 29.78 & 36.41 & 35.92 & 37.16 \\
\hline Rata-rata & 9.93 & 12.14 & 11.97 & 12.38 \\
\hline
\end{tabular}

Berdasarkan Tabel 6, rataan pertambahan bobot badan ayam kampung yang diberi jamu ternak secara berturut-turut adalah $\mathrm{A} 0=9,92 \mathrm{~g}, \mathrm{~A} 1=12,13 \mathrm{~g}, \mathrm{~A} 2=11,97 \mathrm{~g}$ dan $\mathrm{A} 3=12,38 \mathrm{~g}$. Hasil ini sama dengan hasil penelitian Aziana (2005) yang mendapatkan pertambahan bobot badan yaitu $12,89 \mathrm{~g} / \mathrm{ekor} / \mathrm{hari}$ dan hasil penelitia Nurdiani (2005) dengan pertambahan bobot badan pada ayam kampung sebesar $11,14 \mathrm{~g} / \mathrm{ekor} / \mathrm{hari}$.

Dari Tabel 6 juga nampak bahwa pertambahan bobot badan pada perlakuan kontrol (tanpa jamu) lebih rendah dibanding dengan perlakuan dengan pemberian jamu. Hal ini sudah sejalan dengan konsumsi ransum yang juga cenderung meningkat pada perlakuan pemberian jamu. sebagaimana dikemukakan oleh Amrullah (2001) bahwa pertambahan bobot badan dipengaruhi oleh genetik, konsumsi ransum dan kondisi lingkungan.

Wakradihardja dan Erdavit (2003) menyatakan bahwa jamu yang biasa diberi pada ternak mengandung berbagai zat aktif dari tanaman obat tradisional. Jahe, kencur, kunyit lengkuas, daun sirih, bawang putih yang terkandung dalam jamu dapat meningkatkan nafsu makan dan meningkatkan metabolisme tubuh ayam

Tabel 7. Rataan Konversi Pakan Ayam Kampung yang Diberi Jamu Ternak Melalui Air Minum.

\begin{tabular}{lllll}
\hline Ulangan & Perlakuan & \multicolumn{3}{l}{} \\
\cline { 2 - 5 } & A0 & A1 & A2 & A3 \\
\hline 1 & 5.55 & 5.08 & 4.05 & 3.78 \\
2 & 4.78 & 4.02 & 5.4 & 4.37 \\
3 & 4.54 & 4.2 & 4.26 & 4.4 \\
\hline Jumlah & 14.87 & 13.3 & 13.71 & 12.55 \\
\hline Rata-rata & 4.95 & 4.43 & 4.57 & 4.12 \\
\hline
\end{tabular}

Berdasarkan Tabel 7 , rataan konversi pakan ayam kampung yang diberi jamu ternak secara berturut-turut adalah $\mathrm{A} 0=4,95 \mathrm{~g}, \mathrm{~A} 1=4,43 \mathrm{~g}, \mathrm{~A} 2=4,57 \mathrm{~g}, \mathrm{~A} 3=$ $4,18 \mathrm{~g}$. Semakin rendah nilai konversi pakan makasemakin efisien penggunaan pakan olehayam kampung tersebut, karena semakinsedikit jumlah pakan yang dimakan untukmenghasilkan pertambahan bobot badandalam jangka waktu tertentudisebabkan karena konversi pakan pada ternak ayam kampung banyak diperuntukan untuk kebutuhan serat kasar sedangkan untuk pakan yang dikonversi menjadi bobot badan sangat sedikit. 
Pada Tabel 7 dapat dilihat bahwa pemberian jamu ternak dapat menurunkan konversi pakan. Hal ini diduga didalam jamu terdapat bahan-bahan bermanfaat yang dapat memperbaiki konsumsi dan meningkatkan bobot badan yang pada akhirnya dapat menurunkan konversi pakan seperti jahe yang dapat menimbulkan nafsu makan. disamping dapat memperbaiki penggunaan pakan dan dapat memacu pertumbuhan ternak.

Berdasarkan sidik ragam menunjukkan bahwa pada masing-masing perlakuan berpengaruh tidak nyata $(\mathrm{P}>0,05)$. Hal ini sudah sejalan dengan konsumsi pakan dan pertambahan bobot badan yang juga tidak berpengaruh nyata. menurut Nuriadin (2005) bahwa besarnya konversi pakan ditentukan oleh banyaknyakonsumsi pakan dan pertambahan bobotbadan yang diperoleh. Selanjutnya Abidin (2003), menyatakan bahwa konversi pakan diartikan sebagai angka banding dari jumlah pakan yang dikonsumsi dibagi dengan berat badan yang diperoleh.

\section{KESIMPULAN}

\section{Kesimpulan}

Berdasarkan hasil dan pembahasan dapat disimpulkan bahwa penggunaan jamu ternak hingga 3\% melalui air minum berpengaruh tidak nyata $(\mathrm{P}>0,05)$ terhadap konsumsi air minum, konsumsi pakan, pertambahan bobot badan dan konversi pakan.

\section{DAFTAR PUSTAKA}

Abidin, Z., 2003. Meningkatkan Produktifitas Ayam Ras Pedaging. Agromedia Pustaka, Jakarta.

Agustina,L. 2006. Penggunaan Ramuan Herbal Sebagai Feed Additive untuk Meningkatkan Performans
Broiler Prosiding Lokakarya Nasional Inovasi Teknologi dalam Mendukung Usaha Ternak Unggas Berdaya Saing. Pusat Penelitian dan Pengembangan Peternakan Balai Penelitian dan Pengembangan Pertanian Bekerjasama dengan Fakultas Peternakan Universitas Diponegoro. Semarang. Penerbit Pusat Penelitian dan Pengembangan Peternakan, Bogor. Hal. 47-52.

Agustina, M.Hatta dan S.Purwanti. 2009.

Penggunaan Ramuan Herbal

Untuk Meningkatkan

Produktifitas Dan Kualitas

Broiler. 1. Analisis zat bioaktif dan uji aktifitas antibakteri ramuan herbal dalam menghambat bakteri Gram positif dan Gram negatif. Prosiding Seminar Nasional Peternakan Berkelanjutan. Bandung 21-22 Oktober 2009. Fakultas Peternakan Unpad. Hal: 514-517.

Amrullah, I. K. 2003. Nutrisi Ayam Broiler. Lembaga Satu Gunungbudi. Bogor.

Anonim. 2011 a Ramuan Herbal. http://www.multiherbal.net/artikel /arti-ramuan-herbal.(30Mei2016).

Anggorodi, R. 1994. Ilmu Makanan Ternak Umum. Gramedia Pustaka Utama, Jakarta.

Azina W. 2005. Pemberian Neobro dalam

Ransum terhadap Penampilan Ayam Prosiding Lokakarya Nasional Inovasi Teknologi dalam Mendukung Usaha Ternak Unggas Berdaya Saing. Pusat Penelitian dan Pengembangan Peternakan Balai Penelitian dan Pengembangan Kampung Fase Starter. Universitas Halu Oleo, Kendari.

Nurdiani. 2005. Pengaruh Penambahan Neubro pada level yang berbeda terhadap penampilan ayam kampung fase stater. Skripsi. 
Fakultas Pertanian. Universitas Haluoleo. Kendari.

Tillman, A.D., H. Hartadi, S Reksohadiprojodo, Prawirokusumo dan S Lebdosoekojo. 1989. Ilmu Makanan Ternak. Cetakan ke-4. Gadjah Mada University Press. Yogyakarta.

Uzer, F., I. Ning, dan Roesdiyanto. 2013. Penggunaan pakan fungsional dalam ransum terhadap konsumsi pakan dan pertambahan bobot badan ayam broiler. Jurnal Ilmiah peternakan, 1(1):282-288.
Wahyu, J. 2004. Ilmu nutrisi unggas. Gajah Mada University Press. Yogyakarta

S. Wakradiharja, E. dan Erdavit, 2003. Agribisnis Ayam Kampung atau Ayam Buras Akrab Dusun. Penerbit Eka Jaya, Jakarta. 